\title{
Karakteristik Kesetimbangan Adsorpsi Uap Air Film Terbuat dari Karboksi Metil Glukomanan-Karagenan dengan Penambahan Gliserol
}

\author{
Fadilah $^{1, *}$, Ari Diana Susanti ${ }^{1}$, dan Sperisa Distantina ${ }^{1}$ \\ ${ }^{1}$ Program Studi Teknik Kimia, Fakultas Teknik, Universitas Sebelas Maret Surakarta \\ E-mail: fadilah@staff.uns.ac.id (*Corresponding author)
}

\begin{abstract}
Various efforts have done to overcome the enviromental pollution and one of them is to replace plastic with environmentally friendly materials. Glucomannan is a polysaccharide found in porang tubers that can be a source for biodegradable edible film.. For the production of edible film, glucomannan was modified into carboxy methyl glucomannan before it was mixed with carrageenan. Glycerol was added as a plasticizer. The film was made by casting method. Gliserol was added to a mixed solution of carboxy methyl and carrageenan and then poured onto a mold before drying in an electrical oven. Observation of the equilibrium adsorption equilibrium was carried out by gravimetric method for different level of water activity $(0.06-0.97)$ and temperature $\left(30,40\right.$ and $\left.50{ }^{\circ} \mathrm{C}\right)$. The results showed that film with higher glycerol concentrations showed higher equilibrium moisture content. The equilibrium adsorption model, the Oswin equation, is used to describe the water absorption behavior with average error at $20,947-75,271 \%$.
\end{abstract}

Keywords: Carboxymethyl glucomannan-carrageenan film, water vapor equilibrium, Oswin equation.

EQUILIBRIUM Volume 4 No.1 July 2020

Online at http:/ / equilibrium.ft.uns.ac.id 



\section{Pendahuluan}

Tujuan pengemasan diantaranya adalah untuk mempertahankan kualitas bahan pangan. Plastik merupakan pengemas yang ideal, mudah dibentuk baik berupa lembaran, potongan ataupun kerangka. Namun penggunaan plastik sebagai pengemas menyisakan permasalahan yaitu bahwa sampah plastik sulit untuk terdegradasi sehingga mencemari lingkungan.

Untuk mengurangi sampah kemasan maka diperlukan suatu usaha untuk menggantikan kemasan plastik dengan suatu bahan yang mudah terurai atau biodegradable. Eksplorasi terhadap bahan kemasan berbahan dasar bahan biologi yang biodegradable banyak dilakukan. Kemasan berbahan biodegradable tersusun atas polimerpolimer yang dapat didegradasi oleh mikroorganisme melalui proses komposting. Terdapat dua jenis polimer yang biodegradable, yaitu edible dan non-edible. Suatu edible film biasanya dihasilkan dari bahan pangan dan turunannya [1].

Edible film dapat dibentuk sebagai suatu lapisan tipis yang digunakan untuk melapisi makanan (coating), atau suatu free-standing film yang diletakkan di antara komponen yang berfungsi sebagai penahan terhadap transfer massa seperti air, oksigen, dan lemak, atau berfungsi sebagai pembawa bahan tambahan pangan [2].

Edible film dapat dibuat dari bahan dengan sifat "film forming ability". Bahan dengan kategori tersebut dapat dikelompokkan menjadi tiga jenis yaitu hidrokoloida (termasuk di dalamnya adalah protein dan polisakarida), lipida (asam lemak, asigliserol dan wax) dan komposit. Salah satu bahan hidrokoloida yang banyak terdapat di Indonesia adalah glukomanan. Bahan hidrokoloida lain adalah karagenan. Indonesia juga menjadi negara eksportir rumput laut penghasil karagenan nomor empat di dunia, tetapi belum dapat memenuhi permintaan dunia terhadap rumput laut kering yang diprediksi semakin meningkat. Salah satu sifat larutan glukomanan adalah viskositasnya yang tinggi . Sifat ini perlu dimodifikasi. Proses modifikasi kimiawi melalui karboksimetilasi memungkinkan glukomanan memiliki sifat fungsional yang berbeda dengan aslinya sehingga lebih bersinergis saat dicampur dengan karagenan. Dengan viskositas yang rendah maka bahan ini lebih mudah saat diaplikasikan saat dibuat menjadi lembaran. Hal ini merupakan kebaruan dari pekerjaan ini.

Penambahan plasticizer menyebabkan penurunan gaya antarmolekul di sepanjang rantai polimer yang meningkatkan fleksibilitas dan mobilitas rantai. Plasticizer ditambahkan untuk meningkatkan fleksibilitas film, mengurangi kerapuhan, menghindari penyusutan selama penanganan dan penyimpanan dan untuk membuat film lebih mudah untuk dilepaskan dari cetakannya selama pembuatan. Jenis dan konsentrasi plasticizer berperan dalam mengontrol kadar air dan tingkat adsorpsi kelembaban film [3]. Gliserol merupakan salah satu plasticizer yang banyak ditambahkan ke dalam pembuatan film edible.

Sifat film edible dari biopolimer ditentukan oleh jaringan makromolekulnya. Sifat ini tergantung dari kandungan air di dalamnya. Aktivitas air (water activity, aw) merupakan sifat termodinamika bahan yang menjelaskan hubungan antara molekul-molekul air dengan matriks bahan tersebut. Aktivitas air didefinisikan sebagai perbandingan antara tekanan uap air dalam suatu sistem dengan tekanan uap air murni pada suhu yang sama, atau kelembaban relatif setimbang dari udara di sekeliling sistem pada suhu yang sama. Isoterm adsorpsi uap air merupakan ketergantunagn dari kandungan air dalam suatu bahan terhadap aktivitas air pada suhu tertentu [4]. Isotherm adsorpsi uap air merupakan alat yang sangat baik untuk memperkirakan umur simpan suatu produk. Oleh karena itu adalah penting untuk memodelkan data kesetimbangan adsorpsi uap air untuk membantu memperkirakan isotherm adsorpsi pada suhu yang tidak diketahui.

Tujuan dari penelitian ini adalah untuk mempelajari pengaruh suhu dan konsentrasi gliserol terhadap isotherm adsorpsi uap air.

\section{Metode penelitian}

\subsection{Bahan}

Tepung glukomanan dengan tingkat food grade, karagenan dengan tingkat murni (refined), etanol $96 \%$ dan gliserol diperoleh dari lokal Indonesia. Natrium monoklhoro asetat dan natrium hidroksida adalah dengan tingkat reagen analitis (AR-Analytical Reagent Grade) dari Merck.

\subsection{Metode}

Pembuatan karboksi metil glukomanan dilakukan dengan metode yang sama oleh Fadilah [5]. Pembuatan film dilakukan dengan metode pencetakan. Film dibuat dengan mencampurkan karboksi metil glukomanan 
dan karagenan dengan perbandingan massa 5:15; 10:10 dan 15:5 (g/g). Sejumlah 20 gram campuran karboksi metil glukomanan dan karagenan dengan perbandingan tertentu dilarutkan dalam $1000 \mathrm{~mL}$ air. Dilakukan pengadukan dan pemanasan pada suhu $65^{\circ} \mathrm{C}$ selama $1 \mathrm{jam}$. Setelah pengadukan selesai, gliserol ditambahkan dengan komposisi tertentu (10\% dan 15\% (\% berat) terhadap total padatan). Dilakukan pengadukan selama 30 menit yang disertai dengan pemanasan pada $65^{\circ} \mathrm{C}$. Campuran dituangkan ke dalam cetakan dan selanjutnya dikeringkan di dalam oven bersuhu $50{ }^{\circ} \mathrm{C}$ selama 24 jam. Film kering yang diperoleh disimpan dalam wadah tertutup sebelum dilakukan pengujian.

Untuk keperluan pengujian adsorpsi uap air, film dipotong dengan ukuran $30 \mathrm{~mm}$ x $20 \mathrm{~mm}$. Kondisi adsorpsi adalah pada kisaran kelembaban relatif antara 6,1 sampai dengan $97 \%$ (aktivitas air berkisar 0,06 sampai 0,97) yang diatur dengan menggunakan larutan garam lewat jenuh dari Natrium Hidroksida, Magnesium Khlorida, Magnesium Nitrat, Natrium Khlorida, Kalium Khlorida, Barium Khlorida dan Kalium Sulfat pada suatu wadah tertutup rapat. Sampel film ditempatkan pada suatu wadah di atas larutan garam Wadah-wadah keetimbangan ditempatkan di dalam ruang yang terkontrol suhunya dan dibiarkan berkesetimbangan selama 10 hari. Sampel ditimbang untuk mengetahui kadar air dengan menggunakan neraca analitis (dengan ketelitian 0,0001 g) dan berat kering sampel ditimbang setelah pengeringan dalam oven pada suhu $110^{\circ} \mathrm{C}$ selama 4 jam.

\section{Hasil dan Pembahasan}

Tabel 1 dan Tabel 2 menunjukkan data kandungan air setimbang pada berbagai aktivitas air masing-masing untuk kadar gliserol 10\% dan 15\%. Kurva hubungan antara aktivitas air (aw) dengan kandungan air pada film terlihat pada Gambar 1 dan Gambar 2.

Tabel 1. Kandungan air pada berbagai aktivitas air pada film dengan kandungan gliserol 10\%.

\begin{tabular}{lcccccc}
\hline \multicolumn{2}{c}{ suhu $30{ }^{\circ} \mathrm{C}$} & \multicolumn{2}{c}{ suhu $40{ }^{\circ} \mathrm{C}$} & \multicolumn{2}{c}{ suhu $50{ }^{\circ} \mathrm{C}$} \\
\hline $\mathrm{GOH}$ & 0,07 & 0,52 & 0,06 & 0,56 & 0,06 & \\
$\mathrm{MgCl}_{2}$ & 0,32 & 3,21 & 0,32 & 2,42 & 0,31 & 1,19 \\
$\mathrm{Mg}\left(\mathrm{NO}_{3}\right)_{2}$ & 0,51 & 12,64 & 0,48 & 6,95 & 0,45 & 10,24 \\
$\mathrm{NaCl}$ & 0,75 & 26,79 & 0,75 & 21,23 & 0,74 & 42,18 \\
$\mathrm{KCl}$ & 0,84 & 44,06 & 0,82 & 32,06 & 0,82 & 32,89 \\
$\mathrm{BaCl}_{2}$ & 0,90 & 70,72 & 0,89 & 68,04 & 0,87 & 35,81 \\
$\mathrm{~K}_{2} \mathrm{SO}_{4}$ & 0,97 & 173,12 & 0,96 & 127,03 & 0,96 & 129,99 \\
\hline
\end{tabular}

Dari Gambar 1 dan Gambar 2 dapat dilihat bahwa hubungan antara aktivitas air dengan kandungan air adalah mengikuti tipe III yang dikenal sebagai isotherm Flory-Higgins [6]. Pada tipe ini terjadi kenaikan penyerapan uap air yang tinggi saat bahan berada pada aktivitas air yang tinggi. Kenaikan kandungan air meningkat tajam terlihat saat film berada pada aktivitas air di atas 0,8 . Bentuk kurva seperti ini sering ditemui pada bahan-bahan yang mengandung senyawa yang larut dalam air [4]. Pada aktivitas air rendah, penyerapan air terutama dilakukan oleh polimer. Saat aktivitas air tinggi, penyerapan air diserap oleh senyawa lain dengan berat molekul yang lebih rendah yaitu gliserol [7].

Tabel 2. Kandungan air pada berbagai aktivitas air pada film dengan kandungan gliserol 15\%.

\begin{tabular}{lcccccc}
\hline & \multicolumn{2}{c}{ suhu $30{ }^{\circ} \mathrm{C}$} & \multicolumn{2}{c}{ suhu $40{ }^{\circ} \mathrm{C}$} & \multicolumn{2}{c}{ suhu $50{ }^{\circ} \mathrm{C}$} \\
\hline \multicolumn{1}{c}{ Garam } & aw & kadar air, $\%$ & aw & kadar air, $\%$ & aw & kadar air, $\%$ \\
\hline $\mathrm{KOH}$ & 0,07 & 14,21 & 0,06 & 9,52 & 0,06 & 14,48 \\
$\mathrm{MgCl}_{2}$ & 0,32 & 18,84 & 0,32 & 14,12 & 0,31 & 24,90 \\
$\mathrm{Mg}\left(\mathrm{NO}_{3}\right)_{2}$ & 0,51 & 34,36 & 0,48 & 22,79 & 0,45 & 18,58 \\
$\mathrm{NaCl}$ & 0,75 & 36,81 & 0,75 & 32,12 & 0,74 & 40,02 \\
$\mathrm{KCl}$ & 0,84 & 57,46 & 0,82 & 62,10 & 0,82 & 43,90
\end{tabular}

Karakteristik Kesetimbangan Adsorpsi Uap Air Film Terbuat dari Karboksi Metil 


\begin{tabular}{lcccccc}
\hline & \multicolumn{2}{c}{ suhu $30{ }^{\circ} \mathrm{C}$} & \multicolumn{2}{c}{ suhu $40{ }^{\circ} \mathrm{C}$} & \multicolumn{2}{c}{ suhu $50{ }^{\circ} \mathrm{C}$} \\
\hline \multicolumn{1}{c}{ Garam } & aw & kadar air, $\%$ & aw & kadar air, $\%$ & aw & kadar air, $\%$ \\
\hline $\mathrm{BaCl}_{2}$ & 0,90 & 90,46 & 0,89 & 98,69 & 0,87 & 66,38 \\
$\mathrm{~K}_{2} \mathrm{SO}_{4}$ & 0,97 & 228,17 & 0,96 & 179,82 & 0,96 & 142,37 \\
\hline
\end{tabular}

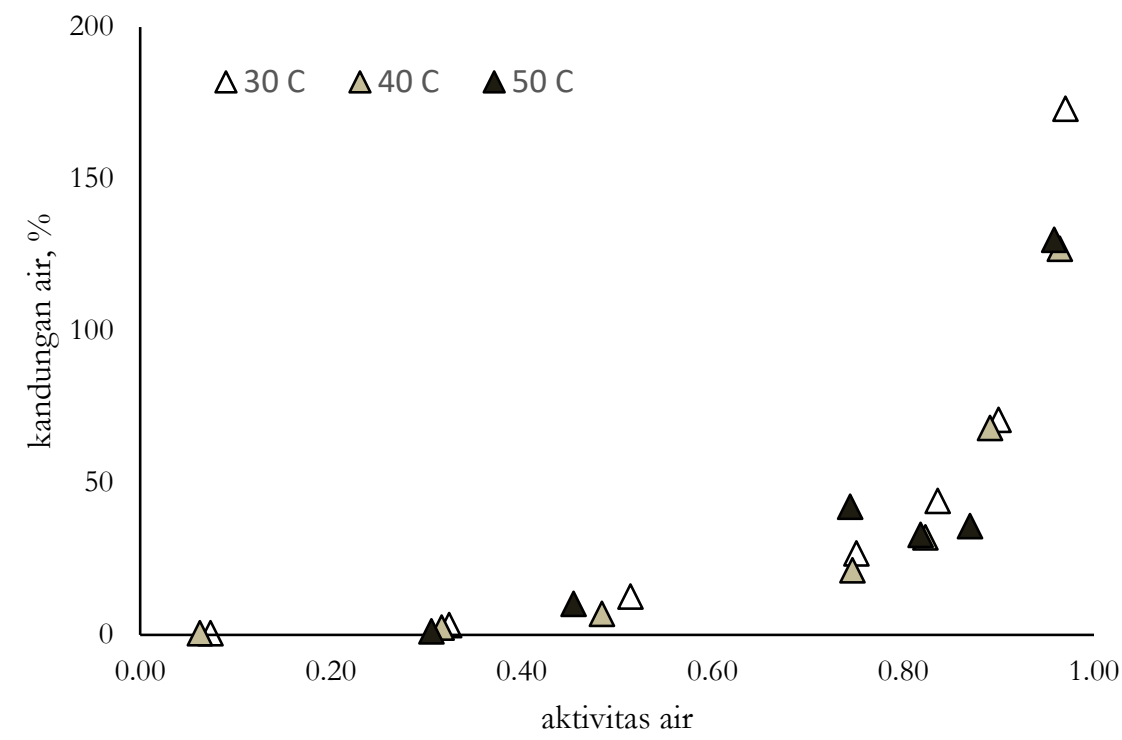

Gambar 1. Hubungan antara aktivitas air dengan kandungan air pada berbagai suhu (kadar gliserol 10\%).

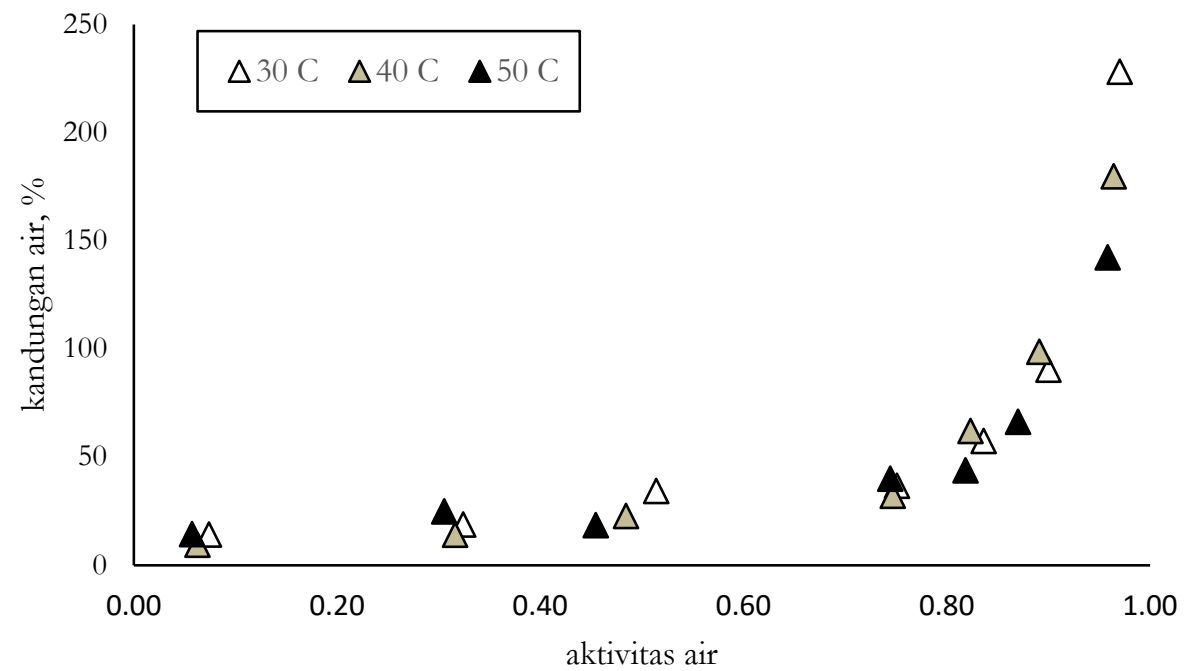

Gambar 2. Hubungan antara aktivitas air dengan kandungan air pada berbagai suhu (kadar gliserol 15\%).

Pengaruh suhu terhadap kesetimbangan adsorpsi uap air dapat dilihat dari Gambar1 dan Gambar2. Baik untuk film dengan kadar gliserol 10\% maupun 15\%, adsorpsi uap air cenderung menurun dengan naiknya suhu lingkungan pada aktivitas air yang sama. Fenomena yang sama diamati oleh Chowdury [8] yang mengamati kesetimbangan adsorpsi uap air oleh film edible yang terbuat dari campuran pati, amilosa dan metal selulosa. Menurut [9] pada suhu yang lebih tinggi molekul air dapat diaktifkan pada tingkat energi yang lebih tinggi, menyebabkan molekul kurang stabil sehingga mudah melepaskan diri dari tempat terikatnya, mengakibatkan berkurangnya kandungan air setimbang.

Pengaruh jumlah gliserol yang ditambahkan dapat dilihat pada Gambar 3, Gambar 4 dan Gambar 5. Dari ketiga gambar tersebut terlihat bahwa kandungan air setimbang adalah lebih tinggi pada kadar gliserol yang lebih besar. Gliserol adalah suatu plasticizer yang membuat film menjadi lebih plastis sehingga tidak kaku. 
Penambahan gliserol akan menyediakan lebih banyak situs aktif yang menyediakan gugus hidroksil hidrofilik dimana molekul air dapat diadsorpsi. Menurut [10] kandungan gliserol yang lebih tinggi menunjukkan kapasitas penyerapan uap air yang lebih tinggi pada kondisi aktivitas air yang sama. Gliserol memiliki ukuran molekul yang kecil yang memungkinkannya berada pada ruang matriks polimer, yang meningkatkan mobilitas molekul air.

Data kesetimbanagn adsorpsi uap air diprediksi dengan menggunakan model Oswin. Pada beberapa pengujian kesetimbangan adsorpsi uap air model Oswin terbukti dapat menggambarkan dengan baik sistem kesetimbangan yang terjadi. Rachnatapun [11] melakukan percobaan kesetimbangan adsorpsi uap air dari film yang terbuat dari CMSr (carboxymethyl Starch rice) dan mendapatkan kesimpulan bahwa isotherm Oswin cocok untuk menggambarkan peristiwa kesetimbangannya. Dalam mengevaluasi kesetimbangan adsorpsi uap air pada film yang terbuat dari pati ketela dan konsentrat protein kedelai Chinma [12] juga mendapati bahwa model Oswin cocok terhadap data percobaan. Gambar 3, Gambar 4 dan Gambar 5 menunjukkan isotherm Oswin yang dipergunakan dalam memodelkan peristiwa adsorpsi uap air oleh film campuran karboksi metil glukomanan dan karagenan pada percobaan yang dilakukan. Nilai parameter Oswin yang diperoleh dapat dilihat pada Tabel 3.

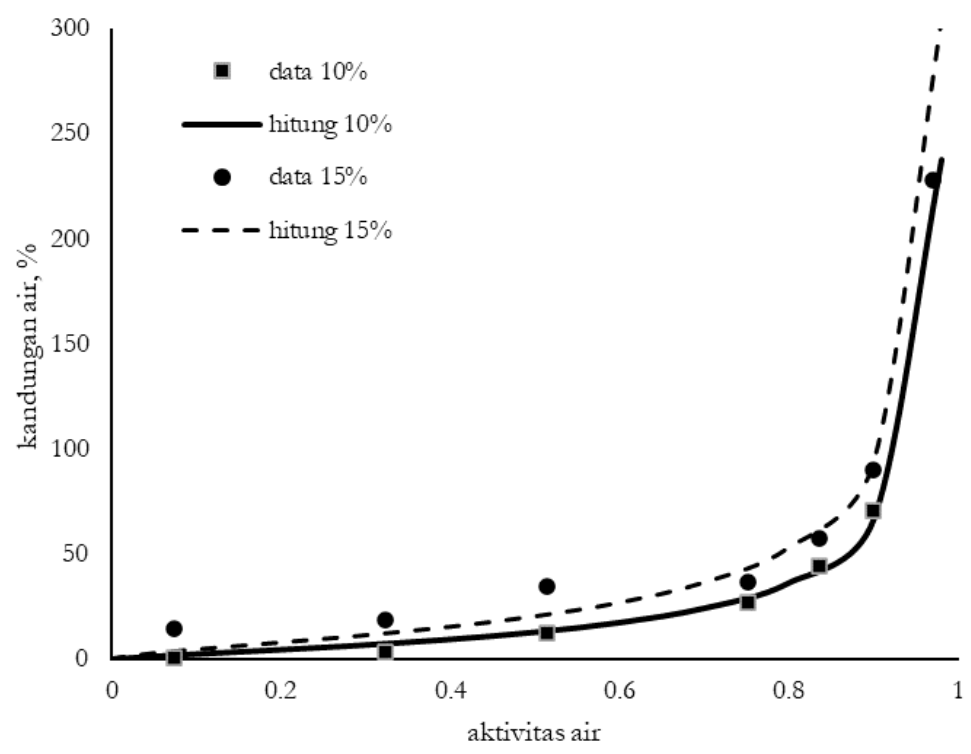

Gambar 3. Data percobaan dan kurva isotherm Oswin adsorpsi uap air oleh film pada kadar gliserol yang berbeda (suhu $30^{\circ} \mathrm{C}$ ).

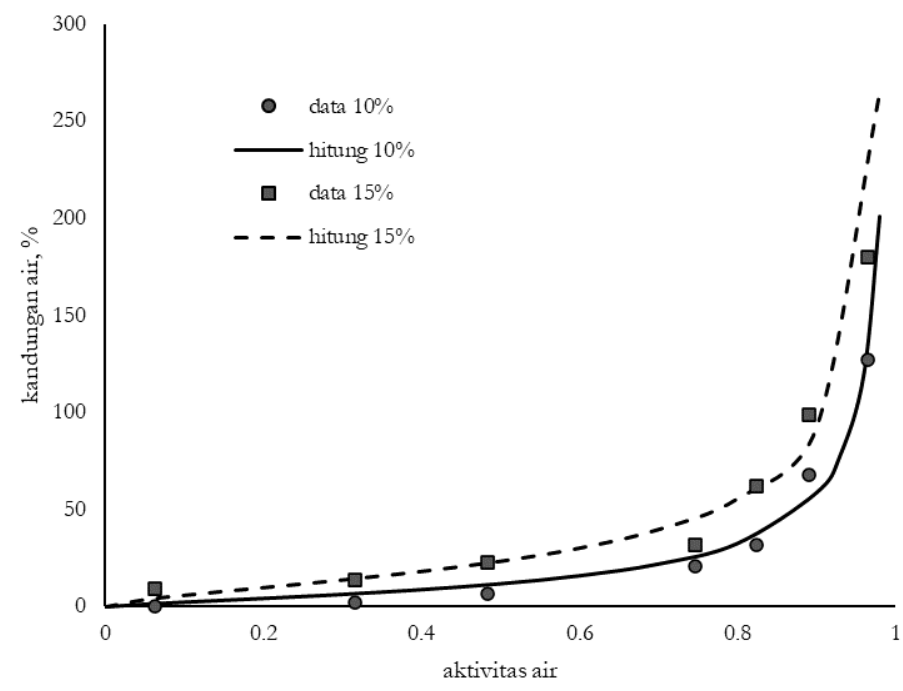

Karakteristik Kesetimbangan Adsorpsi Uap Air Film Terbuat dari Karboksi Metil 
Gambar 4. Data percobaan dan kurva isotherm Oswin adsorpsi uap air oleh film pada kadar gliserol yang berbeda (suhu $40^{\circ} \mathrm{C}$ ).

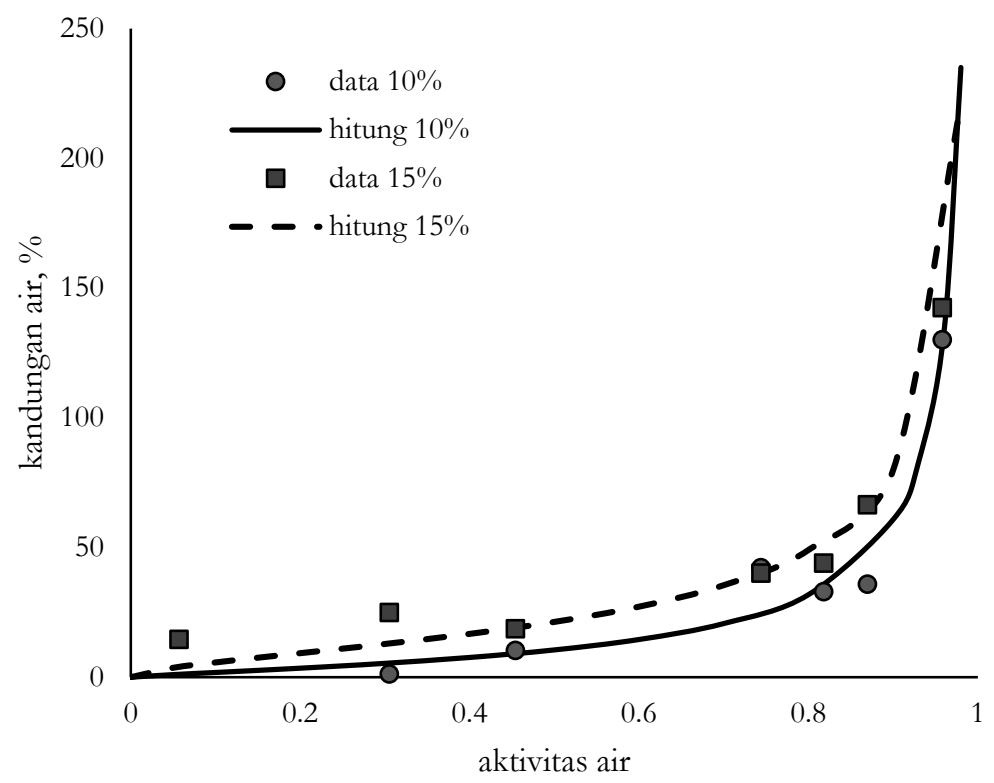

Gambar 5. Data percobaan dan kurva isotherm Oswin adsorpsi uap air oleh film pada kadar gliserol yang berbeda (suhu $50^{\circ} \mathrm{C}$ ).

Tabel 3. Nilai parameter pada persamaan Oswin pada berbagai film beserta ralat reratanya.

\begin{tabular}{ccccc}
\hline & & a & b & $\begin{array}{c}\text { ralat } \\
\text { rerata }\end{array}$ \\
\hline \multirow{2}{*}{ suhu 30 C } & $10 \%$ & 12,878 & 0,749 & 61,340 \\
& $15 \%$ & 20,071 & 0,697 & 25,868 \\
suhu 40 C & $10 \%$ & 11,932 & 0,725 & 71,893 \\
& $15 \%$ & 23,527 & 0,622 & 16,589 \\
suhu 50 C & $10 \%$ & 10,516 & 0,798 & 75,271 \\
& $15 \%$ & 21,312 & 0,601 & 20,947 \\
\hline
\end{tabular}

Nilai ralat yang diperoleh terlihat besar sebenarnya hanya dikontribusi oleh data pada akvivitas air yang rendah. Misalnya pada isotherm untuk film pada kondisi $30^{\circ} \mathrm{C}$, ralat pada aktivitas air 0,07 menyumbang ralat sebesar $274 \%$, sehingga mengakibatkan ralat rata-ratanya adalah besar. Hal ini menunjukkan bahwa model Oswin hanya cocok dipergunakan untuk memperkirakan kesetimbangan adsorpsi uap air pada nilai aktivitas air menengah dan tinggi.

\section{Kesimpulan}

Suhu yang lebih tinggi mengakibatkan nilai kandungan uap air setimbang lebih rendah. Penambahan gliserol akan menaikkan kadar uap air kesetimbangan. Dalam menyatakan hubungan ksetimbangan adsorpsi uap air, Model Oswin memberikan ralat yang relatif besar.

\section{Ucapan terima kasih}

Penulis mengucapkan terima kasih kepada KemristekDikti yang telah membiayai penelitian ini melalui Hibah Fundamental UNS tahun 2019. 


\section{Referensi}

[1] D.Z., Suput, V.L., Lazic, S,Z. Popovic, and N.M Hromis, Edible Films and coating - sources, properties and application, Food and Feed Research, 42 (1), 11-22, 2015.

[2] T. Bourtoom, Edible films and coatings: Characteristics and properties. International Food Research Journal, 15 (3), 237-248, 2008.

[3] S. Mali, L.S. Sakanaka., F Yamashita., M.V.E. Grossmann, Water sorption and mechanical properties of cassava starch films and their relation to plasticizing effect. Carbohydrate Polymers, 60: 283-289, 2005.

[4] M. S. Rahman (editor), Water Activity and Food Preservation, Handbook of Food Preservation, 2 $2^{\text {nd }}$ ed., Boca Raton, CRC Press, 1999, ch. 20, pp. 91-95.

[5] Fadilah, S. Distantina, M. Kaavessina, S.T. Wijayanti, and R. Andayani, Study on the Carboxymethylation of Glucomannan from Porang, AIP Conference Proceedings, 1931, 030005, 2018.

[6] S. Basu, U. S. Shivhare, and A. S. Mujumdar, Models for Sorption Isotherms for Foods: A Review, Drying Technology, 24: 917-930, 2006.

[7] N. A. Aviara, Moisture Sorption Isotherms and Isotherm Model Performance Evaluation for Food and Agricultural Products, DOI: http://dx.doi.org/10.5772/intechopen.87996

[8] T. Chowdhury and M. Das., Moisture Sorption Isotherm and Isosteric Heat of Sorption of Edible Films Made From Ble.nds of Starch, Amylose, and Methyl Cellulose, Int. Food Res. J. 19(4),1669-1678, 2012.

[9] N. D. Menkov and A. G. Durakova., Moisture Sorption Isotherms of Sesame Flour at Several Temperatures Food Technol. Biotechnol. 45 (1), 96-100, 2007.

[10] S.Galus, A.Turska and A. Lenart, Sorption and Wetting Properties of Pectin Edible Films, Crech J. Food Sci, 30, No. 5: 446-455, 2012.

[11] P. Rachtanapun and W. Tongdeesoontorn, Effect of $\mathrm{NaOH}$ Concentration on Sorption Isotherm of Carboxymethyl Rice Starch Films and Prediction Models, Chiang Mai J. Sci.; 38(3) : 380-388, 2011.

[12] C. E. Chinma \& C. C. Ariahu \& J. S. Alakali, Moisture sorption and thermodynamic properties of cassava starch and soy protein concentrate based edible films, International Journal of Food Science and Technology, 48, 2400-2407, 2013. 